\title{
PENERAPAN PRINSIP-PRINSIP PERLINDUNGAN HUKUM MEREK TERKENAL KONVENSI PARIS KE DALAM UNDANG - UNDANG NOMOR 20 TAHUN 2016 TENTANG MEREK DAN INDIKASI GEOGRAFIS
}

\author{
Maolana Alfarizi \\ Universitas Pembangunan Nasional (UPN) Veteran, Jawa Timur, Indonesia \\ email: maolanafariz@gmail.com
}

\begin{abstract}
Indonesia is a country that has the ability to attract business owners to trade goods and services belonging to foreign businesses in Indonesia. So that goods and services are protected by businesses will make maximum protection efforts. In today's business world, we find many famous brands that come from abroad and domestically. The need to protect well-known brands is very important, in the face of violations that occur in the trade of goods and services. Protection of well-known brands is urgently needed to avoid losses to brand holders and consumers who use goods and services. International regulations on well-known brands are regulated in the Paris convention and accommodated by Indonesia through Law No. 20 of 2016 The purpose of this research is to discuss the principles of protection of well-known brand laws in the Paris convention as well as their application after the enactment of Law No. 20 of 2016 on Brands and Geographical Indications. This research uses juridical-normative method, is a method that is done based on the main legal material by studying theories, concepts, legal principles and laws and regulations related to this study. The conclusion of the research shows that the famous brand is a brand that has been known by the general public in the field of business, has a high reputation because it is obtained from a vigorous and massive promotion, investments in several countries in the world made by the owner, and accompanied by proof of registration of the brand in several countries. As for more details on the criteria of well-known brands, described in article 18 paragraph (3) regulation of the Minister of Law and Human Rights No. 67 of 2016 concerning Brand Registration.
\end{abstract}

Keywords: legal protection; famous brands 


\begin{abstract}
Abstrak
Indonesia adalah negara yang memiliki kemampuan untuk menarik para pemilik usaha untuk memperdagangkan barang dan jasa milik pelaku usaha asing yang ada di Indonesia. Agar barang dan jasa terlindungi para pelaku usaha akan melakukan upaya perlindungan yang maksimal. Dalam dunia usaha saat ini, banyak sekali kita jumpai merek-merek terkenal yang berasal dari luar maupun dalam negeri. Kebutuhan untuk melindungi merek terkenal menjadi hal yang sangat penting, dalam menghadapi pelanggaran-pelanggaran yang terjadi dalam perdagangan barang dan jasa. Perlindungan terhadap merek terkenal sangat dibutuhkan untuk menghindari kerugian pemegang merek dan konsumen pemakai barang dan jasa. Peraturan internasional tentang merek terkenal sudah diatur dalam konvensi paris dan diakomodasi Indonesia melalui Undang-Undang Nomor 20 Tahun 2016. Tujuan penelitian ini untuk membahas mengenai prinsip perlindungan hukum merek terkenal dalam konvensi paris serta penerapannya setelah berlakunya Undang-Undang Nomor 20 Tahun 2016 tentang Merek dan Indikasi Geografis. Penelitian ini menggunakan metode yuridis-normatif, merupakan metode yang dilakukan berdasarkan bahan hukum utama dengan cara menelaah teori-teori, konsep-konsep, asas-asas hukum serta peraturan perundang-undangan yang berhubungan dengan penelitian ini. Kesimpulan penelitian menunjukkan bahwa merek Terkenal adalah merek yang telah diketahui oleh masyarakat umum di bidang usaha, memiliki reputasi tinggi karena diperoleh dari promosi yang gencar dan besar-besaran, investasi di beberapa negara di dunia yang dilakukan oleh pemiliknya, dan disertai bukti pendaftaran merek tersebut di beberapa Negara. Adapun secara lebih detail mengenai kriteria merek terkenal, dijelaskan dalam pasal 18 ayat (3) Peraturan Menteri Hukum dan Hak Asasi Manusia Nomor 67 Tahun 2016 Tentang Pendaftaran Merek.
\end{abstract}

Kata Kunci: perlindungan hukum; merek terkenal

\title{
Pendahuluan
}

Setiap korporasi atau perusahaan yang memproduksi barang atau jasa untuk memajukan usaha dan roda perekonomiannya menggunakan banyak strategi, salah satunya dengan menggunakan merek. Sebagaimana fungsinya, merek digunakan untuk memberikan identitas sebagai pembeda terhadap barang komoditas atau produk yang dihasilkan suatu perusahaan atau jasa dengan barang atau produk perusahaan lain yang sejenis. Tidak terbayangkan apabila suatu produk barang atau jasa yang dipasarkan tanpa menggunakan merek, tentunya konsumen akan sulit untuk membedakan barang dari produk suatu perusahaan yang satu dengan perusahaan lainnya. Oleh karena itu merek merupakan identitas atau tanda pengenal suatu barang yang sekaligus menjadi penghubung antara produsen dan konsumen. Hal itu menjadi jaminan kepribadian (individuality), dan reputasi barang atau jasa hasil usahanya tersebut pada waktu diperdagangkan. 
Merek dapat pula menjadi asset perusahaan apabila produk barang atau jasa yang dihasilkan dengan menggunakan merek tersebut berhasil menjadi barang atau jasa yang banyak diminati dan digunakan oleh sebagian besar masyarakat. Maka dari itu nerek yang bersangkutan akan menjadi "kata kunci" bagi masyarakat yang akan membeli suatu barang (Raharjo, 1999).

Dari sejarah perkembangannya, diketahui bahwa hukum merek yang berkembang pada pertengahan abad XIX, sebagai bagian dari hukum yang mengatur masalah persaingan curang dan pemalsuan barang. Norma dasar dari perlindungan merek adalah bahwa tidak seorang pun berhak menawarkan kepada masyarakat seolah-olah sebagai barang hasil produksi usahanya. Lambat laun perlindungan diberikan sebagai suatu pengakuan bahwa merek tersebut sebagai milik dari orang yang memakainya sebagai tanda pengenal dari barang-barangnya dan untuk membedakannya dari barang-barang lain yang tidak menggunakan merek tersebut. Pengakuan tersebut didasarkan pada pengenalan atau pengetahuan masyarakat bahwa merek dagang itu berfungsi sebagai ciri pembeda. Pengenalan tersebut mendorong masyarakat untuk membeli barang yang memakai merek tertentu itu, sehingga menjadikannya objek hak milik (property rights) dari pemilik merek tersebut (Jened, 2000).

Secara yuridis, dalam Pasal 1 ayat (1) Undang-undang Nomor 20 Tahun 2016 tentang Hak Merek dan Indikasi Geografis telah memberikan pengertian atau definisi mengenai merek, ekplisit tertulis merek adalah Tanda yang dapat ditampilkan secara grafis berupa gambar, logo, nama, kata, huruf, angka, susunan warna, dalam bentuk 2 (dua) dimensi dan/atau 3 (tiga) dimensi, suara, hologram, atau kombinasi dari 2 (dua) atau lebih unsur tersebut untuk membedakan barang dan/atau jasa yang diproduksi oleh orang atau badan hukum dalam kegiatan perdagangan barang dan/atau jasa. Selanjutnya Merek Dagang adalah Merek yang digunakan pada barang yang diperdagangkan oleh seseorang atau beberapa orang secara bersama-sama atau badan hukum untuk membedakan dengan barang sejenis lainnya. Adapun Merek Jasa menurut Pasal 1 ayat (5) Undang-undang Nomor 20 tahun 2016 tentang Hak Merek dan Indikasi Geografis adalah Merek yang digunakan pada jasa yang diperdagangkan oleh seseorang atau beberapa orang secara bersama-sama atau badan hukum untuk membedakan dengan jasa sejenis lainnya.

Adapun menurut pengertian beberapa sarjana, Merek menurut Yusran Isnaini adalah tanda yang berupa gambar, nama, kata, huruf-huruf, angkaangka, susunan warna, atau kombinasi dari unsur-unsur tersebut yang memiliki daya pembeda dan digunakan dalam kegiatan perdagangan barang atau jasa (Isnaini, 2010). Menurut Prof. Molengraaf, merek adalah dengan mana dipribadikanlah sebuah barang tertentu, untuk menunjukkan asal barang, dan jaminan kualitasnya sehingga bias dibandingkan dengan barang-barang sejenis yang dibuat dan diperdagangkan oleh orang atau perusahaan lain (Djumhana 
\& Djubaedillah, 2014). Menurut H.M.N Purwo Sutjipto, merek dapat diartikan suatu tanda, dengan mana suatu benda tertentu dipribadikan sehingga dapat dibedakan dengan benda lain yang sejenis (Sutjipto \& Purwo, 1984).

Merek sebagai sarana pemasaran dan periklanan (a marketing and advertising device) memberikan suatu tingkat informasi tertentu kepada konsumen mengenai barang dan/atau jasa yang dihasilkan pengusaha. Lebihlebih dengan perkembangan periklanan, baik nasional maupun internasional dewasa ini dan dalam rangka mendistribusikan barang dan/atau jasa membuat merek semakin tinggi nilainya. Merek yang didukung dengan media periklanan membuat pengusaha memiliki kemampuan menstimulasi permintaan konsumen sekaligus mempertahankan loyalitas konsumen (consumer's loyalty) atas produk dan/atau jasa yang dihasilkannya Inilah yang menjadikan merek sebagai suatu keunggulan kompetitif (competitive advantage) dan keunggulan kepemilikan (ownership advantages) untuk bersaing di pasar global (Jened, 2000).

Arti penting sebuah merek, sehingga melekat didalamnya Hak ekonomi dan hak moral yang tidak bisa dipisahkan dari hak kekayaan intelektual. Hak moral adalah hak agar ciptaan tidak diubah atau dirusak tanpa persetujuan dan hak untuk diakui sebagai pecipta ciptaan tersebut (Haris Munandar dan Sally Sitanggang, 2008). Sedangkan menurut Pasal 1 ayat (5) Undang-undang Nomor 20 tahun 2016 tentang Hak Merek dan Indikasi Geografis Hak atas Merek adalah Hak eksklusif yang diberikan oleh negara kepada pemilik Merek yang terdaftar untuk jangka waktu tertentu dengan menggunakan sendiri Merek tersebut atau memberikan izin kepada pihak lain untuk menggunakannya. Dari definisi pasal 1 angka 5 diatas mencakup lisensi hak ekonomi dan hak moral.

Perlunya perlindungan hukum terhadap merek karena mempunyai hak moral dan hak ekonomi yang sangat bernilai atas suatu barang dan jasa yang menunjukkan kualitas barang tertentu dalam perdagangan. Untuk mendapatkan perlindungan hukum, suatu merek harus didaftarkan. Pendaftaran merek juga berguna sebagai dasar penolakan terhadap merek yang sama pada keseluruhannya atau sama pada pokoknya yang dimohonkan oleh orang atau perusahaan lain dengan itikad tidak baik untuk barang atau jasa sejenis (Hasibuan, 2003).

Kebutuhan untuk melindungi merek terkenal menjadi hal yang sangat penting, dalam menghadapi pelanggaran-pelanggaran yang terjadi dalam perdagangan barang dan jasa. Perlindungan terhadap merek terkenal sangat dibutuhkan untuk menghindari kerugian pemegang merek dan konsumen pemakai barang dan jasa. Pelanggaran terhadap merek terkenal mengakibatkan menurunnya kepercayaan konsumen terhadap merek tersebut, karena konsumen menganggap barang dan jasa yang mutunya baik tersebut 
kualitasnya sudah menurun. Hal ini mengakibatkan berkurangnya omzet penjualan, sehingga merugikan pemegang merek. Selain itu, konsumen akan memperoleh barang atau jasa yang mutunya lebih rendah dibandingkan dengan merek asli yang sudah terkenal. Karena berada dalam ranah antar negara, keberadaan asas dan kaidah hukum tentang perlindungan terhadap merek terkenal pertama kali merupakan asas dan kaidah yang diletakkan oleh hukum internasional. Pada gilirannya, asas dan kaidah hukum internasional tersebut harus diimplementasikan dan diaplikasikan oleh negara dalam forum domestiknya. Asas dan kaidah hukum internasional yang memberikan perlindungan hukum terhadap merek terkenal tidak akan efektif tanpa diimplementasikan dalam tata hukum nasional masing-masing negara yang dibebani kewajiban internasional tersebut (Nurul Intan Sari, 2015).

Dalam dinamika dan realita saat ini, banyak sekali terjadi sengketa dalam bidang merek. Munculnya suatu merek baru yang kemudian eksis di tengahtengah masyarakat dengan meniru atau menjiplak secara keseluruhan atau sama pada pokoknya dengan merek terkenal yang telah didaftarkan dan digunakan oleh perusahaan lain dianggap sebagai bencana bagi perusahaan. Maka kehadiran perangkat hukum yang didalamnya memuat prinsip-prinsip perlindungan hukum mampu melindungi merek terkenal memang sangat dibutuhkan oleh setiap badan usaha.

Indonesia memberi perhatian lebih kepada HKI dengan bergabung menjadi anggota organisasi internasional, salah satunya yaitu Paris Convention yang kemudian diratifikasi dengan Keppres No. 15 Tahun 1997 dan juga menandatangani TRIPs (Trade Related Aspect of Intellectual Property Rights) Agreement dan meratifikasinya melalui Keppres No.7 Tahun 1997. Dengan diratifikasinya Paris Convention dan TRIPs Agreement maka Indonesia wajib untuk menyesuaikan undang-undang yang ada dengan ketentuan yang diatur dalam perjanjian internasional tersebut (Windari, 2014).

Adapun ketentuan-ketentuan yang substantif dalam Konvensi Paris dapat dibagi ke dalam tiga kategori utama, yaitu prinsip national treatment, hak prioritas (right of priority), dan ketentuan-ketentuan umum (common rules) (Azed, 2006).

Di Indonesia pengaturan tentang merek sebagaimana di atur dalam ketentuan Undang-Undang Nomor 15 Tahun 2001 tentang Merek yang telah diubah dengan Undang-Undang Nomor 20 tahun 2016 tentang Merek dan Indikasi Geografis yang meratifikasi dari konvensi paris pada tahun 1979. Yang akar atau basis dari aturan ini terdapat pada Article 5 (2) Paris Conventions:

"Use of trademark by the proprietor in a from differing in elements which do not alter the distinctive character of the mark in the from in wich it was 
registered in one of the countries of the union shall not entail invalidation of registration and shall not disminish the protection granted to the mark".

Terjemahan bebasnya adalah Penggunaan merek dari pemilik dalam bentuk dengan unsur-unsur yang berbeda tetapi tidak menghilangkan karakter pembeda dari dalam bentuk dimana merek tersebut didaftarkan di satu Negara peserta konvensi, tidak mengakibatkan pembatalan dari pendaftarannya dan tidak menghilangkan perlindungan yang telah diberikan sebagai merek terdaftar (Jened, 2000).

Sebelumnya ada penelitian lain yang berjudul Perlindungan Hukum Terhadap Merek Terkenal Berdasarkan Konvensi Paris Dan Perjanjian Trips Serta Penerapannya Berdasarkan Undang-Undang Nomor 15 Tahun 2001 Tentang Merek membahas mengenai perlindungan hukum merek terkenal dalam konvensi paris ke dalam Undang-Undang Merek yang sebelumnya, dan yang membedakan dengan penelitian ini adalah fokus dengan prinsip perlindungan hukum merek terkenal dalam konvensi paris yang diratifikasi ke dalam Undang Undang No. 20 Tahun 2016 serta penerapannya dalam putusan pengadilan di Indonesia. Dalam penelitian ini, penulis akan menganalisa penerapan prinsip perlindungan hukum merek terkenal Paris Convention for the Protection of Industrial Property (Konvensi Paris) Khususnya pada Article 2 \& 6 yang diantaranya terdapat prinsip national treatment, hak prioritas, dan ketentuan-ketentuan umum. Prinsip-prinsip ini sangat penting diratifikasi maupun diterapkan kedalam pengaturan perlindungan hukum merek terkenal di Indonesia karena menjadi payung hukum terhadap merek-merek terkenal yang belum terdaftar bagi domestik maupun internasional dan melindungi dari jiplakan yang ingin membonceng merek terkenal tersebut, maka penulis akan menganalisis apakah prinsip-prinsip tersebut telah diakomodasi kedalam aturan Undang Undang Nomor 20 Tahun 2016 tentang Merek dan Indikasi Geografis serta penerapan perlindungan merek terkenal dalam putusan pengadilan di Indonesia yaitu Putusan Nomor 119 PK/Pdt.Sus-HKI/2017, yang merupakan kasus sengketa merek terkenal, serta menganalisa putusan hakim tersebut telah mengarah pada perlindungan hukum terhadap merek terkenal berdasarkan setelah berlakunya undang-undang merek tersebut.

Atas dasar ketertarikan pada pembahasan mengenai merek terkenal tersebut sehingga peneliti disini ingin meneliti dan menuangkannya didalam sebuah tulisan yang berjudul "Penerapan Prinsip-Prinsip Perlindungan Hukum Merek Terkenal Paris Convention dalam Undang - Undang Nomor 20 Tahun 2016".

Penelitian ini diharapkan dapat memberikan sumbangsih pemikiran dalam pemahaman teori yang telah ada dan dalam praktek hukum terkait dengan penerapan prinsip - prinsip perlindungan hukum dalam hal 
memberikan perlindungan terhadap merek terkenal sesuai dengan ketentuan perundang-undangan yang berlaku, yaitu Undang-Undang Nomor 20 tahun 2016 tentang Merek dan Indikasi Geografis (ratifikasi dari Konvensi Paris)

\section{Metode Penelitian}

Penelitian ini menggunakan metode yuridis-normatif, merupakan metode yang dilakukan berdasarkan bahan hukum utama dengan cara menelaah teoriteori, konsep-konsep, asas-asas hukum serta peraturan perundang-undangan yang berhubungan dengan penelitian ini. Pendekatan ini dikenal pula dengan pendekatan kepustakaan, yakni dengan mempelajari buku-buku, peraturan perundang-undangan dan dokumen lain yang berhubungan dengan penelitian ini. Yuridis-normatif menggunakan konsepsi legis positivis. Konsep ini memandang hukum identik dengan norma-norma tertulis yang dibuat dan diundangkan oleh lembaga atau pejabat yang berwenang. Konsepsi ini memandang hukum sebagai suatu sistem normatif yang bersifat mandiri (Soemitro, 1990).

Penelitian ini menggunakan pendekatan perundang-undangan (statute aproach) dan pendekatan kasus (case aproach). Pendekatan perundangundangan digunakan untuk mengetahui keseluruhan peraturan hukum khususnya hukum di Indonesia. Pendekatan kasus bertujuan untuk mepelajari penerapan norma-norma atau kaidah hukum yang dilakukan dalam praktik hukum. Terutama mengenai kasus-kasus yang telah diputus sebagaimana yang dapat dilihat dalam yurisprudensi terhadap perkara-perkara yang menjadi fokus peneltian ini (Ibrahim, 2006).

Objek penelitian ini adalah peraturan perundang-undangan dan konvensi internasional terkait dengan Merek. Objek Penelitian ini juga menyangkut Putusan-putusan Pengadilan yang telah memiliki kekuatan hukum tetap (inkracht).

Data penelitian diperoleh dari kegiatan Library reseach, dari bahan hukum primer maupun sekunder, berupa putusan-putusan, perundangundangan terkait, serta buku-buku, Jurnal, pendapat para ahli, serta bahan lain yang relevan dengan penelitian.

Penelitian yang dilakukan oleh penulis mengacu kepada pendekatan peraturan perundang-undangan dan pendekatan kasus. Pendekatan peraturan perundang-undangan dilakukan dengan cara menelaah semua undang-undang dan regulasi, dalam hal ini termasuk undang-undang dan konvensi internasional terkait dengan merek, yaitu Konvensi Paris. Pendekatan kasus dilakukan dengan cara meneliti kasus yang berkaitan dengan isu yang sedang dihadapi, yang dalam hal ini adalah kasus merek terkenal. Dengan demikian penelitian ini akan mendapatkan jawaban dari permasalahan yang diangkat dalam penelitian ini. 
Adapun analisa data yang dilakukan dalam penelitian ini adalah secara kualitatif. Data yang diperoleh diolah dengan metode kualitatif, yaitu dinyatakan oleh sumber, baik secara lisan maupun tulisan yang dipelajari sebagai sesuatu yang utuh, yaitu dengan menggabungkan antara permasalahan dan data yang diperoleh untuk tercapainya kesimpulan tertentu sehingga diperoleh hasil yang signifikan dan ilmiah. Proses analisis data dalam penelitian kualitatif dimulai dengan menelaah seluruh data yang terkumpul dari berbagai sumber. Tujuan dari penelitian ini adalah untuk mengungkap fakta, keadaan, fenomena, variabel yang terjadi saat penelitian dan menyuguhkannya secara objektif (Admin, 2020).

\section{Hasil dan Pembahasan}

\section{A. Prinsip-Prinsip Perlindungan Merek Terkenal Konvensi Paris Diakomodasi Undang Undang Nomor 20 Tahun 2016}

\section{Prinsip Perlindungan Merek Terkenal Menurut Konvensi Paris}

Konvensi internasional yang secara signifikan dan menjadi dasar bagi konsep Industrial Property, khususnya mengenai marks atau merek adalah Paris Convention for Protection of Industrial Property Rights (Konvensi Paris). Konvensi Paris dimulai pada tanggal 20 Maret 1883, dengan ditandatangani oleh 11 (sebelas) negara peserta. Dalam perkembangannya, Konvensi Paris mengalami beberapa perubahan yaitu di Brussels tanggal 14 Desember 1900, Washington tanggal 2 Juni 1911, Den Haag tanggal 6 November 1925, London tanggal 2 Juni 1934, Lisbon tanggal 31 Oktober 1958, Stockholm tanggal 14 Juli 1967 dan terakhir diubah di Jenewa pada tanggal 28 September 1979.

Berikut ini adalah beberapa prinsip - prinsip dalam konvensi paris yang relevan atau terkait dengan perlindungan hukum merek terkenal :

a. National Treatment

Salah satu prinsip terpenting dari Konvensi Paris adalah tentang persamaan perlakuan yang mutlak antara orang asing dengan warga negara sendiri. Prinsip national treatment atau prinsip assimilasi (principle of assimilation) yaitu bahwa seorang warga negara dari suatu negara peserta, akan memperoleh pengakuan dan hak-hak yang sama seperti seoarang warga negara dimana mereknya didaftarkan. Prinsip National Treatment berlaku bagi setiap Negara pesertanya, yang berarti antara warga Negara dari Negara-negara sesama peserta Konvensi Paris harus diberikan perlindungan hukum yang sama seolah warga Negara tersebut sedang berada di negaranya sendiri, sehingga warga Negara tersebut diperlakukan sama dengan warga Negara dari peserta yang bersangkutan. 
Terkait dengan perlindungan merek terkenal secara internasional diatur dalam Pasal 6bis Konvensi Paris yang kemudian diadopsi kedalam TRIPs Agreement melalui Pasal 16 ayat (2) dan diadopsi pula oleh Penjelasan Pasal 21 ayat (1) huruf b Undang-Undang Merek Nomor 20 Tahun 2016. Selengkapnya berbunyi sebagai berikut:

"Aricle 6 bis of Paris Convention (1967) shall apply, mutatis mutandis, to service. In determining whether a trade mark is wellknown member state shall take account of the knowladge of the knowladge of the trademark in relevant sectors of the public, including knowladge in the members concerne which has been obtained as a result of the promotion of the trademark

Terjemahan: pasal 6bis Konvensi Paris (1967) berlaku, mutatis mutandis, untuk layanan atau jasa. Dalam menentukan apakah suatu merek dagang terkenal negara anggota harus mempertimbangkan pengetahuan di sektor terkait dari masyarakat,termasuk pengetahuan dalam anggota yang bersangkutan yang telah diperoleh sebagai hasil dari promosi merek dagang di sektor terkait dari masyarakat, termasuk pengetahuan dalam anggota yang telah diperoleh sebagai hasil dari promosi merek dagang".

Sebagai Negara yang telah menandatangai Konvensi Paris dan persetujuan tentang Aspek-aspek Dagang Hak Kekayaan Intelektual (Agreement on Trade Related Aspect of Intellectual Property Rights, Including Trade in Company Goods/TRIPs), sudah seharusnya Indonesia melindungi merek terkenal. Sampai saat ini masih dipermasalahkan tentang definisi apa yang disebut dengan merek terkenal. Tolok ukur yang digunakan masih belum jelas. Batasan suatu merek sebagai merek terkenal tidaklah terbatas untuk merekmerek yang dimiliki oleh pihak asing saja, tetapi juga merek-merek lokal yang dimiliki oleh pengusaha nasional yang berhasil go international. Apakah suatu merek termasuk sebagai merek terkenal, selain didasarkan pada Pasal 6bis Konvensi Paris, juga didasarkan pada Undang- Undang Merek yang berlaku atau didasarkan pula pada interpretasi hakim dalam mengadili.

b. Hak Prioritas (right of priority)

Hak prioritas dalam perlindungan HKI hanya diperuntukkan bagi negara-negara sesama yang tergabung dalam Paris Convention atau persetujuan pembentukan organisasi perdagangan dunia. Konvensi Paris mengatur mengenai prinsip atau hak prioritas dalam hal paten, merek dan desain industri bersumber juga pada pasal 6bis yang asas asasnya telah digabungkan di dalam TRIPs. Ketentuan- 
ketentuan Paris Convention yang terpenting dalam hak prioritas adalah sebagai berikut: (Purwaningsih, 2005)

Penggunaan hak prioritas atas dasar permintaan pendaftar pertama di negara anggota, pemohon dapat di dalam periode tertentu 6 atau 12 bulan meminta perlindungan seolah-olah didaftarkan pada hari yang sama pada permintaan pertama. Khusus bagi negara bukan anggota diberlakukan asas principle of independence, artinya pemberian HKI di suatu negara tidak mewajibkan negara lain memberikan HKI. Inti dari pengertian prioritas adalah menggunakan tanggal penerimaan permintaan pendaftaran atau filling date. Jadi hak prioritas berkaitan dengan jangka waktu pendaftaran yang memberikan anggapan mendaftar lebih awal dari fakta yang sesungguhnya. Berarti disini hak prioritas adanya berdasarkan permohonan, dan tidak terjadi dengan sendirinya secara otomatis. Maksud dari pengertian prioritas adalah dengan menggunakan dan menempatkan tanggal penerimaan dianggap sama dengan tanggal penerimaan di negara asal. Dianggap sama tentunya dalam arti seolah-olah, bukan yang sesungguhnya. Berarti ini adalah suatu fiksi suatu anggapan (Sufiarina, 2012).

Hal ini berarti bahwa berdasarkan pendaftaran yang pertama kali diajukan oleh Negara peserta, pendaftar dapat dalam waktu 6 bulan untuk merek terkenal, mendaftar untuk perlindungan di Negara peserta lainnya yang akan dianggap sebagai pendaftaran pada hari yang sama saat pendaftaran pertama kali dilakukan. Dengan kata lain, pendaftaran yang dilakukan belakangan tersebut akan memiliki hak prioritas atas aplikasi-aplikasi yang diajukan selama periode tersebut oleh orang lain atas penemuan, merek atau desain industri yang sama. Hak prioritas menghendaki tidak ada diskriminasi bagi warga negara asing dalam mendaftarkan HKInya di negara yang tergabung dalam persetujuan Paris Convention atau Persetujuan Pembentukan Organisasi Perdagangan Dunia.

Selain tergabung di dalam Paris Convention, Indonesia juga menandatangani beberapa perjanjian/agreement, salah satunya yang terbaru adalah TRIPs Agreement (Trade Related aspects of Intellectual Property Rights) yang merupakan perjanjian yang paling komprehensif dalam bidang HKI, dimana semua negara anggota WTO terikat oleh TRIPs Agreement tersebut. Dalam perjanjian tersebut semua negara anggota diwajibkan menyesuaikan hukum domestik agar sesuai dengan persyaratan - persyaratan dalam TRIPs Agreement (Hadi, 2003). 
Perlindungan hukum terhadap merek terkenal spesifik terdapat dalam TRIPs Agreement Pasal 16 ayat (1), (2) dan (3). untuk barang atau jasa sejenis terdapat dalam ketentuan TRIPs Agreement Pasal 16 ayat (1), Pemilik merek terkenal memiliki hak eksklusif terhadap mereknya. Dengan hak eksklusif pada pemilik merek, perlindungan hukum terhadap merek terkenal untuk; barang atau jasa sejenis adalah dengan cara mencegah atau menggugat pihak lain yang menggunakan merek terkenal tanpa seizin pemilik merek. Pasal 6 bis Paris Convention diadopsi dalam Pasal 16 ayat (2) dan (3) Trips Agreement. Pada ketentuan Pasal 16 ayat (2) Trips Agreement tersebut, perlindungan hukum diberikan terhadap merek terkenal untuk merek jasa sebagaimana perlindungan hukum dalam ketentuan Pasal 6 bis Paris Convention. Ketentuan dalam Pasal 16 ayat (2) Trips Agreement berlaku mutatis mutandis dengan Pasal 6 bis Paris Convention terhadap jasa, bahwa untuk menentukan apakah suatu merek terkenal atau tidak, para anggota harus mempertimbangkan pengetahuan mengenai merek di sektor publik, yang relevan, termasuk pengetahuan anggota mengenai hal mana yang didapat sebagai hasil promosi merek. Perlindungan hukum untuk merek terkenal untuk barang atau jasa tidak sejenis, terdapat dalam ketentuan Pasal 16 ayat (3) Trips Agreement yang juga mutatis mutandis dengan Pasal 6 bis Paris Convention. Pasal ini menentukan bahwa perlindungan merek terkenal diperluas tidak hanya mencakup barang sejenis saja melainkan juga terhadap barangbarang yang tidak sejenis. Namun, pengertian barang-barang yang tidak sejenis dalam pasal ini, tidak menyebutkan apakah mencakup barang-barang yang berbeda kelas (Nurul Intan Sari, 2015).

\section{Perlindungan Merek Terkenal Dalam Undang-Undang Republik Indonesia Nomor 20 Tahun 2016 tentang Merek dan Indikasi Geografis}

Indonesia menjadi anggota Konvensi Paris sejak menandatangani Konvensi Paris pada tanggal 12 Januari 1968 dan kemudian meratifikasi Konvensi Paris melalui Keputusan Presiden Nomor 24 Tahun 1979 dan diperbaharui dengan Keputusan Presiden Nomor 15 Tahun 1997 Tentang Perubahan Keputusan Presiden Nomor 24 Tahun 1979 Pengesahan Paris Convention For The Protection Of Industrial Property dan Convention Establishing The World Intellectual Property Organization. Beberapa hal yang diatur dalam konvensi paris adalah tentang syarat- syarat pendaftaran merek, yang dituangkan pula kedalam aturan legislasi nasional di setiap Negara peserta. 
Selanjutnya, dalam hukum nasional pengaturan tentang merek diatur dalam Undang-undang Nomor 20 Tahun 2016 tentang Merek dan Indikasi Geografis. UU No. 20 Tahun 2016 merupakan penggantian dari UU No. 15 Tahun 2001 tentang Merek. Salah satu substansi perubahan dalam UU No. 20 Tahun 2016 adalah aturan yang lebih ketat terhadap merek terkenal dibanding UU Merek yang lama, UU No. 15 Tahun 2001 (UU Merek). Penegakan perlindungan hukum merek terkenal di Indonesia sudah dimulai sejak Undang-Undang No. 15 Tahun 2001 tentang Merek, tetapi dalam naskahnya belum dijelaskan secara rinci apa itu merek terkenal serta payung hukumnya bagaimana, adapun dijelaskan sebatas permohonannya saja yaitu dalam pasal 6 ayat (1). Penyempurnaannya dijelaskan lebih rinci dalam Undang-Undang No. 20 Tahun 2016 tentang Merek dan Indikasi Geografis, salah satu perubahannya adalah aturan yang lebih ketat terhadap merek terkenal dibanding UU Merek yang lama, UU No. 15 Tahun 2001. UU Merek yang baru (UU No. 20 Tahun 2016) membuka peluang bagi pemegang merek terkenal mengajukan gugatan ke pengadilan apabila terjadi pelanggaran merek (Purwaka, 2017).

Adapun Undang-Undang Nomor 20 Tahun 2016 tentang Merek dan Indikasi Geografis mengatur tentang perlindungan merek terkenal yang diakomodasi dari prinsip Paris Convention dalam beberapa pasal. Berikut ini beberapa pasal dalam Undang-Undang Nomor 20 Tahun 2016 tentang Merek dan Indikasi Geografis yang memuat prinsip perlindungan hukum merek terkenal dalam Konvensi Paris :

1. Hak Prioritas

a. Pasal 9 dan 10 Undang-Undang No. 20 Tahun 2016 tentang Merek dan Indikasi Geografis

Dalam Pasal 9 dan 10 menyatakan permohonan dengan menggunakan Hak Prioritas harus diajukan dalam waktu paling lama 6 (enam) bulan terhitung sejak tanggal penerimaan permohonan pendaftaran merek yang pertama kali diterima di negara lain yang merupakan anggota Konvensi Paris tentang Pelindungan Kekayaan Industri (Paris Convention for the Protection of Industrial Property) atau anggota Persetujuan Pembentukan Organisasi Perdagangan Dunia (Agreement Establishing the World Trade Organization)." Selain harus memenuhi ketentuan sebagaimana dimaksud Permohonan dengan menggunakan Hak Prioritas wajib dilengkapi dengan bukti penerimaan permohonan pendaftaran Merek yang pertama kali menimbulkan Hak Prioritas tersebut. Bukti wajib diterjemahkan ke dalam bahasa Indonesia. Jika ketentuan tersebut 
tidak dipenuhi dalam waktu paling lama 3 (tiga) bulan setelah berakhirnya hak mengajukan permohonan dengan menggunakan Hak Prioritas sebagaimana dimaksud, permohonan tersebut tetap diproses tetapi tanpa menggunakan Hak Prioritas.

b. Pasal 35 Undang-Undang No. 20 Tahun 2016 tentang Merek dan Indikasi Geografis

Adapun dalam pasal tersebut menyatakan merek terdaftar mendapat pelindungan hukum untuk jangka waktu 10 (sepuluh) tahun sejak tanggal penerimaan dan jangka waktu pelindungan itu dapat diperpanjang. dapat dilihat bahwa Undang-Undang memberikan pelindungan terhadap suatu merek terdaftar untuk jangka waktu 10 tahun sejak tanggal penerimaan serta dapat diajukan permohonan untuk diperpanjang oleh pemilik untuk jangka waktu yang sama. Sedangkan dalam Paris Convention tidak ditentukan mengenai jangka waktu pelindungan terhadap merek terkenal. Hal ini disesuaikan dengan ketentuan masingmasing negara anggota.

Dapat dianalisa bahwa Undang-undang Merek yang berlaku saat ini memberikan pelindungan terhadap merek yang terdaftar dalam Daftar Umum Merek sebagaimana dimaksud dalam Pasal 35 UU No. 20 Tahun 2016 tentang Merek, yaitu selama 10 (sepuluh) tahun lamanya. Jangka waktu pelindungan tersebut dapat diperpanjang lagi dengan mengajukan permohonan perpanjangan pelindungan terhadap merek yang sama. Jangka waktu pelindungan dapat diperpanjang untuk jangka waktu yang sama. Permohonan perpanjangan diajukan secara elektronik atau nonelektronik dalam bahasa Indonesia oleh pemilik merek atau Kuasanya dalam jangka waktu 6 (enam) bulan sebelum berakhirnya jangka waktu pelindungan bagi merek terdaftar tersebut dengan dikenai biaya. Permohonan perpanjangan disetujui jika melampirkan surat pernyataan tentang: a. Merek yang bersangkutan masih digunakan pada barang atau jasa sebagaimana dicantumkan dalam sertifikat merek tersebut; dan b. barang atau jasa masih diproduksi dan/atau diperdagangkan.

Di dalam pasal-pasal ini memuat mengenai pengaturan Hak Prioritas yang diakomodasi dari prinsip perlindungan hukum merek terkenal yang terdapat dalam Konvensi Paris dalam pasal 6 bis yang sudah sejalan memenuhi kriteria perlindungan hukum merek terkenal bagi negara anggota Konvensi Paris tentang Pelindungan Kekayaan Industri (Paris Convention for the Protection of Industrial Property) 
2. National Treatment

a. Pasal 3 Undang-Undang No. 20 Tahun 2016 tentang Merek dan Indikasi Geografis

Sebagai konsekuensi dari sistem konstitutif yang dianut oleh Undang-Undang No. 20 Tahun 2016 tentang Merek dan Indikasi Geografis, dalam pasal tersebut menyatakan suatu hak atas merek baru dapat tercipta setelah adanya pendaftaran. Dengan melakukan pendaftaran pemilik merek akan memperoleh hak atas penggunaan merek tertentu atau untuk memberikan izin kepada pihak lain untuk menggunakanya selama jangka waktu tertentu serta mendapatkan perlindungan hukum dari Negara.

Memang sebenarnya tidak ada suatu kewajiban bagi sesorang untuk mendaftarakan merek yang dimilikinya, akan tetapi jika merek yang telah dimilikinya didaftarkan kepada Menteri Hukum dan Hak Asasi Manusia maka ia akan mendapat perlindungan hukum. Suatu permohonan merek akan diterima dan diberikan hak atas perlindungan merek apabila telah memenuhi persyararatan baik formalitas maupun substansial yang ditentukan Undang-Undang No. 20 Tahun 2016 tentang Merek dan Indikasi Geografis, dimana dalam hal ini perlindungan merek terkenal dalam hal pendaftaran merek ialah diberikanya kewenangan kepada menteri untuk menolak merek yang mempunyai persamaan pada pokoknya atau keseluruhanya dengan merek terkenal milik pihak lain.

b. Pasal 21 ayat (1) huruf b dan c Undang-Undang No. 20 Tahun 2016 tentang Merek dan Indikasi Geografis

Dalam pasal tersebut menyatakan permohonan ditolak jika merek tersebut mempunyai persamaan pada pokoknya atau keseluruhannya dengan merek terkenal milik pihak lain untuk barang dan atau jasa sejenisnya dan merek terkenal milik pihak lain untuk barang dan atau jasa tidak sejenis yang memenuhi persyaratan tertentu. Ukuran suatu merek dapat dikatakan sebagai merek terkenal (well-known marks) dapat dilihat pada bagian Penjelasan Pasal 21 ayat (1) huruf b Undang-Undang Republik Indonesia Nomor 20 Tahun 2016 tentang Merek dan Indikasi Geografis. Adapun penjelasan pasalnya, penolakan Permohonan yang mempunyai persamaan pada pokoknya atau keseluruhan dengan Merek terkenal milik pihak lain untuk barang dan/atau jasa yang sejenis dilakukan dengan memperhatikan pengetahuan umum masyarakat mengenai Merek tersebut di bidang usaha yang bersangkutan. Di samping itu, 
diperhatikan pula reputasi Merek tersebut yang diperoleh karena promosi yang gencar dan besar-besaran, investasi di beberapa negara di dunia yang dilakukan oleh pemiliknya, dan disertai bukti pendaftaran Merek dimaksud di beberapa negara. Jika hal tersebut belum dianggap cukup, Pengadilan Niaga dapat memerintahkan lembaga yang bersifat mandiri untuk melakukan survei guna memperoleh kesimpulan mengenai terkenal atau tidaknya Merek yang menjadi dasar penolakan.

c. Pasal 42 Undang-Undang No. 20 Tahun 2016 tentang Merek dan Indikasi Geografis

Didalam pasal tersebut mengatur tentang Lisensi yaitu izin yang diberikan oleh pemilik merek terdaftar kepada pihak lain berdasarkan perjanjian secara tertulis sesuai peraturan Perundang-Undangan untuk menggunakan merek terdaftar. Pemilik Merek terdaftar dapat memberikan Lisensi kepada pihak lain untuk menggunakan Merek tersebut baik sebagian maupun seluruh jenis barang dan/atau jasa. Perjanjian Lisensi berlaku di seluruh wilayah Negara Kesatuan Republik Indonesia, kecuali bila diperjanjikan lain dan wajib dimohonkan pencatatannya kepada Menteri dengan dikenai biaya. dan diumumkan dalam Berita Resmi Merek. Perjanjian Lisensi dilarang memuat ketentuan baik yang langsung maupun tidak langsung yang menimbulkan akibat yang merugikan perekonomian Indonesia atau memuat pembatasan yang menghambat kemampuan bangsa Indonesia dalam menguasai dan mengembangkan teknologi.

Dalam hal perlindungan merek terkenal, lisensi pada hakikatnya merupakan suatu institusi yang disediakan hukum untuk melindungi properti seseorang, dimana berfungsi untuk mencegah penyalahgunaan merek terkenal oleh pihak yang tidak berhak serta memberikan kebebasan kepada seseorang atas persetujuan pihak pemilik merek untuk menggunakan mereknya. Lisensi merek memiliki fungsi perlindungan rangkap atau dua pihak, yaitu pemilik merek (licensor) dan pihak yang diberikan izin menggunakan (licensee) (Kurnia \& Darumurti, 2015).

d. Pasal 76 ayat (1) Undang-Undang No. 20 Tahun 2016 tentang Merek dan Indikasi Geografis

Menyatakan bahwa salah satu alasan suatu merek dapat dimintai pembatalanya apabila ialah memiliki persamaan pada pokok dan keseluruhanya dengan merek terkenal pihak lain sebagaimana yang diantur dalam pasal 21 ayat (1) huruf b, 
dimana tampak suatu perbedaan khusus yang diberikan untuk melidungi merek terkenal. Merek terkenal dapat dilindungi tanpa adanya suatu pendaftaran merek terlebih dahulu. Pendaftaran merek di Indonesia menganut sistem konstitutif (harus didaftarkan), namun perlindungan terhadap merek terkenal akan tetap diberikan kepada merek terkenal apabila terbukti nantinya pendaftar tersebut mendaftarakan mereknya dengan unsur melanggar itikad baik. maka selanjutnya pemohon atau pemilik merek terkenal dapat mengajukan pembatalan merek.

e. Pasal 83 ayat (1) Undang-Undang No. 20 Tahun 2016 UndangUndang No. 20 Tahun 2016 tentang Merek dan Indikasi Geografis

Menyatakan keberpihakanya pada kedudukan merek terkenal dimana dalam pada Pasal 83 ayat (1) secara nyata diakomodirnya perlindungan merek terkenal berupa gugatan ganti rugi dan penghentian semua kegiatan yang berhubungan dengan merek meskipun merek terkenal tersebut belum terdaftar, upaya hukum ini dapat dilakukan berdasarkan putusan pengadilan.

Menurut O.K. Saidin dalam bukunya Aspek Hukum Hak Kekayan Intelektual membagi ganti rugi menjadi dua bentuk yaitu ganti rugi secara materill dan ganti rugi secara immateril. Ganti rugi materil yaitu ganti rugi yang berupa kerugian yang nyata dan dapat dinilai dengan uang. Misalnya akibat pemakai merek yang tidak berhak tersebut menyebabkan produk dan barangnya menjadi sedikit yang terjual oleh karena konsumen membeli produk yang menggunakan merek palsu yang di prosuksi oleh pihak yang tidak berhak tersebut. Jadi secara kuantitas terdapat banyak barang yang beredar di pasaran. Sedangkan ganti rugi immateril yaitu berupa tuntutan ganti rugi yang disebabkan oleh pemakaian merek dengan tanpa hak sehingga pihak yang berhak menderita kerugian secara moril. Misalnya pihak yang tidak berhak atas merek tersebut memproduksi barang dengan kualitas (mutu) yang rendah, dengan kemungkinan berakibat kepada konsumen sehingga ia tidak mengkonsumsi produk yang dikeluarkanya oleh pemilik merek yang bersangkutan. Hal inilah yang belum pernah diatur dalam Undang-Undang merek sebelumnya (Saidin, 2004).

Ketentuan tentang persaingan curang ini dapat kita simpulkan tidak hanya berkepentingan untuk melindungi merek, terutama merek terkenal, namun juga untuk mengakomodir perlindungan masyarakat dari penyesatan atau mengecoh 
khalayak ramai (misleading) yang dilakukan oleh pemilik merek yang mempunyai itikad tidak baik. Dalam kaitan ini, pengaturan yang terdapat dalam Undang-Undang No. 20 Tahun 2016 sebagaimana terdapat dalam pasal-pasal tersebut sejalan dengan Pasal 6 bis Paris Convention yang memuat prinsip national treatment atau prinsip assimilasi (principle of assimilation) yaitu bahwa seorang warga negara dari suatu negara peserta, akan memperoleh pengakuan dan hak-hak yang sama seperti seoarang warga negara dimana mereknya didaftarkan.

\section{B. Penerapan Perlindungan Merek Terkenal Setelah Berlakunya Undang- Undang No 20 Tahun 2016 Tentang Merek Dan Indikasi Geografis}

Terkait dengan penerapan perlindungan merek terkenal, penulis akan menggunakan metode studi kasus. Adapun kasus-kasus yang akan diuraikan adalah Gudang Garam Vs Gudang Baru, Skyworth Group vs Linawaty Hardjono dan HUGO Boss vs Teddy Tan.

1. Analisis Kasus Gudang Garam Vs Gudang Baru

Gudang Garam (Penggugat) adalah pemilik dan pemegang hak atas logo Merek dan variannya yang telah terdaftar di Indonesia sebanyak 79 nomor pendaftaran di beberapa kelas barang dan jasa terutama kelas 34 untuk melindungi jenis-jenis barang sigaret kretek. Seiring dengan perkembangan waktu, Merek Gudang Garam telah menjadi Merek yang cukup terkenal dan populer di negaranya sendiri Indonesia, maupun di beberapa negara di dunia.

Permasalahan muncul ketika Gudang Baru (tergugat) menjiplak atau meniru produk milik Gudang Garam. Berdasarkan hal tersebut, sepatutnya Penggugat sangat keberatan dengan terdaftarnya Merek GudangBaru + Lukisan atas nama Tergugat karena mempunyai persamaan pada pokoknya dengan merek Gudang Garam milik Penggugat yang telah terdaftar dalam Daftar Umum Merek Ditjen HKI.

Pendaftaran Merek Gudang Baru + Lukisan atas nama Tergugat tersebut jelas diajukan dengan itikad tidak baik (dishonesty purpose) yaitu untuk mengecoh dan memperdaya khalayak ramai (misleading), seakan-akan Merek serta hasil-hasil produk Gudang Baru + Lukisan atas nama Tergugat berasal dari Penggugat. Sulit dapat dibayangkan pula dari mana kata Gudang Baru+Lukisan diperoleh, kecuali telah diilhami oleh Merek Gudang Garam milik Penggugat.

Dalam kasus tersebut menghasilkan sebuah putusan judex factie, dalam hal ini adalah Pengadilan Niaga Surabaya yang dimenangkan oleh Gudang Garam. Setelah menerima putusan dari Pengadilan Niaga Surabaya, tergugat mengajukan upaya hukum kasasi ke Mahkamah Agung. Putusan kasasi tersebut ternyata berbalik dengan memenangkan 
Gudang Baru. Selanjutnya terdapat novum atau bukti baru berupa sebuah putusan pidana yang menyebabkan Gudang Garam mengajukan peninjauan kembali dan dimenangkan oleh pihak Gudang Garam.

Menurut hemat penulis, Putusan yang dijatuhkan oleh Majelis Hakim Peninjauan Kembali telah tepat dalam menerapkan hukum dan secara formil maupun materiil telah sesuai dengan ketentuan perundang-undangan. Sebagaimana pertimbangan-pertimbangan yang diuraikan oleh penulis sebagai berikut:

Majelis Hakim Kasasi keliru dalam menafsirkan ketentuan Pasal 21 ayat (1) huruf a, b dan c Undang-undang Nomor 20 Tahun 2016 TentangMerek Dan Indikasi Geografis yang secara tegas menyebutkan:

Permohonan ditolak jika Merek tersebut mempunyai persamaan pada pokoknya atau keseluruhannya dengan

a. Merek terdaftar milik pihak lain atau dimohonkan lebih dahulu oleh pihak lain untuk barang dan/atau jasa sejenis;

b. Merek terkenal milik pihak lain untuk barang dan/atau jasa sejenis;

c. Merek terkenal milik pihak lain untuk barang dan/atau jasa tidak sejenis yang memenuhi persyaratan tertentu.

Terkait dengan adanya novum atau bukti baru yang diajukan oleh pemohon peninjauan kembali menjadi point penting dalam perkara ini. merupakan bukti hukum yang menentukan dan membuktikan bahwa Termohon PK sudah dijatuhi putusan pidana yang sudah in kracht van geweisde atau sudah berkekuatan hukum tetap yang bersifat final and binding.

Adapun secara administrative, terkait dengan status merek Termohon sebagaimana ketentuan pasal 21 ayat (3) Undang-undang 20 Tahun 2016 bahwa permohonan merek harus ditolak jika diajukan oleh Pemohon yang beriktikad tidak baik. Pemohon yang beriktikad tidak baik adalah Pemohon yang patut diduga dalam mendaftarkan Mereknya memiliki niat untuk meniru, menjiplak, atau mengikuti Merek pihak lain demi kepentingan usahanya menimbulkan kondisi persaingan usaha tidak sehat, mengecoh, atau menyesatkan konsumen. Contohnya Permohonan Merek berupa bentuk tulisan, lukisan, logo, atau susunan warna yang samadengan Merek milik pihak lain atau Merek yang sudah dikenal masyarakat secara umum sejak bertahun-tahun, ditiru sedemikian rupa sehingga memiliki persamaan pada pokoknya atau keseluruhannya dengan Merek yang sudah dikenal tersebut. Dari contoh tersebut sudah terjadi iktikad tidak baik dari Pemohon karena setidaktidaknya patut diketahui adanya unsur kesengajaan dalam meniru Merek yang sudah dikenal tersebut. 
Sebagaimana dipertimbangkan oleh Judex Facti sebelumnya bahwa merek "Gudang Baru" beserta variannya didaftarkan oleh Termohon Peninjauan Kembali dengan itikad tidak baik karena membonceng (freeriding) untuk meniru merek Pemohon Peninjauan Kembali yang sudah dikenal luas di masyarakat Indonesia, sehingga hal ini merugikan Pemohon Peninjauan Kembali. Oleh karena itu, demi hukum harus dibatalkan.

2. Analisis Kasus Skyworth Vs Linawaty Hardjono

Skyworth Group Co., Ltd., adalah Perusahaan terkenal dari China yang mulai berdiri sejak Tahun 1988 berdasarkan bukti Sertifikat yang diterbitkan oleh Pemerintah China dan sudah lama dikenal di berbagai Negara di dunia, terdaftar untuk jenis barang elektronik berupa Handphone, Televisi, Digital Video, DVD Record, Video Disc Portble, CD Player, Radio, Tape Recorder, Microphone, Video Camera dengan Merek dagang dan Logo Skyworth.

Linawaty Hardjono, dengan tanpa persetujuan telah mendaftarkan merek dagang dan Logo Skyworth ke Direktorat Jenderal Hak Kekayaan Intelektual, Tentunya Penggugat sangat keberatan atas pendaftaran merek SKYWORTH tersebut. Merek dagang dan Logo Skyworth sangat jelas mempunyai persamaan pada pokoknya maupun keseluruhannya untuk jasa-jasa yang sejenis maupun yang tidak sejenis dengan merek dan Logo Skyworth milik Penggugat.

Adanya fakta tersebut jelas telah membuktikan iktikad tidak baik dari Pihak Tergugat untuk mengambil alih meniru serta menjiplak ketenaran merek Skyworth milik Penggugat yang sudah dikenal diberbagai Negara. Maka apabila kedua merek tersebut digunakan secara bersamaan dalam dunia usaha atau bisnis, sudah pasti akan menimbulkan persaingan yang menyesatkan masyarakat luas (misleading) yang membeli barang-barang tersebut seolah-olah barang yang dibeli Konsumen tersebut barang-barang benar produksi Penggugat yang menggunakan merek Skyworth adalah barang/jasa yang berasal dari produksi Penggugat dan hal tersebut tentunya berdampak merugikan Penggugat.

Permasalahan yang ditimbulkan oleh Skyworth Group membuat permohonan pendaftaran merek yang diajukan ditolak oleh Direktur Jenderal Hak Kekayaan Intelektual Hak Kekayaan Intelektual dengan alasan telah menerima pendaftaran merek barang dan jasa Skyworth dari Linawaty Hardjono. Dampak ditolaknya permohonan pendaftaran tersebut sangat merugikan Skyworth Group karena tidak dapat memasukkan barang untuk kelas barang tersebut ke Indonesia. 
Dalam kasus tersebut terhadap putusan yang dijatuhkan oleh Majelis Hakim Peninjauan Kembali yang membatalkan Putusan Kasasi menurut hemat penulis sudah tepat dalam menerapkan hukum dan secara formil maupun materiil telah sesuai dengan ketentuan perundang-undangan yang berlaku. Sebagaimana analisis yang diuraikan oleh penulis sebagai berikut:

Dalam putusan kasasinya Judex Juris telah melakukan kekhilafan hakim atau kekeliruan yang nyata karena telah membatalkan Putusan JudexFacti/ Pengadilan Niaga pada Pengadilan Negeri Jakarta Pusat dengan menyatakan menolak gugatan. Putusan Judex Facti/Pengadilan Niaga pada Pengadilan Negeri Jakarta Pusat telah tepat dan benar dalam putusannya karena telah berani melakukan Judicial Activism, dengan memberi perlindungan bagi Merek Terkenal tidak sejenis, walau belum ada Peraturan Pelaksanaannya karena Indonesia adalah participant atau penanda tangan World Trade Organization Agreements dengan TRIP's sebagai lampirannya dan Paris Convention sehingga berkewajiban melindungi Merek Terkenal termasuk yang tidak sejenis sudah sesuai dengan prinsip perlindungan merek terkenal yang ada di dalam pasal 6 bis Paris Convention.

Maksud dari klausul "Pemohon yang beriktikad tidak baik" adalah Pemohon yang patut diduga dalam mendaftarkan Mereknya memiliki niat untuk meniru, menjiplak, atau mengikuti Merek pihak lain demi kepentingan usahanya menimbulkan kondisi persaingan usaha tidak sehat, mengecoh, atau menyesatkan konsumen. Contohnya Permohonan Merek berupa bentuk tulisan, lukisan, logo, atau susunan warna yang sama dengan Merek milik pihak lain atau Merek yang sudah dikenal masyarakat secara umum sejak bertahun- tahun, ditiru sedemikian rupa sehingga memiliki persamaan pada pokoknya atau keseluruhannya dengan Merek yang sudah dikenal tersebut. Dari contoh tersebut sudah terjadi iktikad tidak baik dari Pemohon karena setidaktidaknya patut diketahui adanya unsur kesengajaan dalam meniru Merek yang sudah dikenal tersebut.120

Hal tersebut diaminkan oleh Putusan Majelis Hakim Peninjauan Kembali dengan menyatakan Linawaty Hardjono telah beriktikad tidak baik dalam mengajukan permohonan merek dagang/jasa Skyworth dengan Merek Nomor Skyworth-RGB.

3. Analisis Kasus Hugo Boss Vs Teddy Tan

Hugo Boss adalah pemilik/pemegang hak atas merek dagang "HugoBoss" serta merek-merek yang mengandung unsur kata "Hugo" dan/atau“Boss" (beserta variasinya) yang merupakan merek terdaftar di Indonesia serta telah menjadi merek terkenal di berbagai negara dan 
sudah dikenal luas di pasaran serta digunakan di berbagai Negara dalam produksi, pemasaran dan/atau penjualan atas produk-produk berupa pakaian, alat mandi, aksesoris lainnya.

Adapun di Indonesia, Hugo Boss juga telah mendaftarkan merek pertama kali pada tanggal 24 Januari 1989 dengan Nomor yang kemudian kembali diperpanjang tertanggal perpanjangan pendaftaran 28 April 2009.

Permasalahan terjadi ketika Teddy Tan telah mendaftarkan merekmerek "Hugo" kepada Kementerian Hukum dan Ham bahkan dengan sengaja telah memperdagangkan, mendistribusikan, dan/atau memasarkan produk-produknya dengan menggunakan merek-merek yang mengandung kata "Hugo" dengan tanpa izin yang memiliki persamaan pada pokoknya maupun pada keseluruhannya dengan merek Hugo Boss (beserta variasinya).

Dalam kasus tersebut menghasilkan putusan Judex Facti Pengadilan Niaga Jakarta Pusat yang memenangkan pihak Teddy Tan dengan pertimbangan memiliki daya pembeda dengan merek Hugo Boss, kemudian pihak Hugo Boss mengajukan kasasi terhadap Teddy Tan dengan pertimbangan tidak puas dengan keputusan Judex Facti Pengadilan Niaga Jakarta Pusat yang menghasilkan putusan kasasi dimenangkan oleh pihak Hugo Boss. Berdasarkan pertimbangan hukum jelas terlihat Majelis Hakim Judex Facti telah keliru karena menyatakan merek- merek Teddy Tan (Termohon Kasasi) masih memiliki daya pembeda dengan merek- merek Hugo Boss. Majelis Hakim Judex Facti juga lalai dalam mencermati detail persamaan pada pokok merek yang sengaja dibuat oleh Teddy Tan pada merek-merek "Hugo" yang disengketakan. Terdapat kemiripan atau menyerupai merek Hugo Boss (beserta variasinya) dengan Teddy Tan. Dalam pertimbangan hukum tersebut, juga terlihat bahwa secara tidak langsung Majelis Hakim Judex Facti mengakui di antara merek-merek tersebut telah terdapat persamaan pada pokoknya dengan elemen kata "Hugo".

Menurut hemat penulis, point ini sangat penting untuk diperhatikan karena menyangkut diterima atau ditolaknya permohonan merek berdasarkan Undang-undang Merek. Sebagaimana secara eksplisit dijelaskan pada pasal 20 dan pasal 21 Undang-undang Nomor 20 Tahun 2016 Tentang Merek dan Indikasi Geografis. Merek tidak dapat didaftar jika tidak memiliki daya pembeda dan Permohonan ditolak jika Merek tersebut mempunyai persamaan pada pokoknya atau keseluruhannya dengan:

a. Merek terdaftar milik pihak lain atau dimohonkan lebih dahulu oleh pihak lain untuk barang dan/atau jasa sejenis; 
b. Merek terkenal milik pihak lain untuk barang dan/atau jasa sejenis.

Selanjutnya, Permohonan ditolak jika diajukan oleh Pemohon yang beriktikad tidak baik. Dalam perkara a quo, memang merek-merek "Hugo" yang disengketakan sudah terlanjut terdaftar pada Direktorat Merek yang dalam hal ini Teddy Tan. Namun hal tersebut tidak menutup kemungkinan adanya kekhilafan dari pejabat yang berwenang ketika melakukan pemeriksaan merek-merek tersebut. Oleh sebab itu, seharusnya Hakim Judex Facti memberikan koreksi atas kesalahan tersebut dengan membatalkan merek-merek terdaftar yang disengketakan. Menurut pendapat penulis bahwa negara seharusnya memberikan sarana koreksi terhadap merek-merek yang sudah terlanjur terdaftar. Mengacu pada ketentuan pasal 76 ayat (3) Undang-undang Merek bahwa Gugatan pembatalan diajukan kepada Pengadilan Niaga terhadap pemilik Merek terdaftar.

Adapun secara lebih detail dijelaskan dalam pasal 18 ayat (3) Peraturan Menteri Hukum dan Hak Asasi Manusia Nomor 67 Tahun 2016 Tentang Pendaftaran Merek, sebagai berikut:

Dalam menentukan kriteria Merek sebagai Merek terkenal dilakukan dengan mempertimbangkan:

a. Tingkat pengetahuan atau pengakuan masyarakat terhadap Merek tersebut di bidang usaha yang bersangkutan sebagai Merek terkenal;

b. Volume penjualan barang dan/atau jasa dan keuntungan yang diperoleh dari penggunaan merek tersebut oleh pemiliknya;

c. Pangsa pasar yang dikuasai oleh Merek tersebut dalam hubungannya dengan peredaran barang dan/atau jasa di masyarakat;

d. Jangkauan daerah penggunaan Merek;

e. Jangka waktu penggunaan Merek;

f. Intensitas dan promosi Merek, termasuk nilai investasi yang dipergunakan untuk promosi tersebut;

g. Pendaftaran Merek atau permohonan pendaftaran Merek di negara lain.

Kesimpulan dari studi 3 kasus tersebut antara Gudang Garam Vs Gudang Baru, Skyworth Group Vs Linawaty Hardjono dan Hugo Boss Vs Teddy Tan bahwa penerapan perlindungan hukum merek terkenal setelah berlakunya Undang Undang No. 20 Tahun 2016 tentang Merek dan Indikasi Geografis telah terpenuhi dan terlindungi dengan baik juga sudah sesuai dengan prinsip-prinsip perlindungan hukum merek terkenal yang ada dalam Paris Convention dan Undang Undang No. 20 Tahun 2016 tentang Merek dan Indikasi Geografis. Terdapat catatan yang seringkali terjadi, yaitu kekhilafan hakim yang salah menafsirkan mengenai merek-merek terkenal dan kekhilafan pejabat yang berwenang 
mengenai pendaftaran beberapa merek yang sudah terpakai atau terkenal di Indonesia maupun negara lain, tetapi dalam hal peraturan dan regulasi sudah cukup jelas dan tegas tercantum dalam pasal 21 Undang Undang No. 20 Tahun 2016 tentang Merek dan Indikasi Geografis serta pasal 18 ayat (3) Peraturan Menteri Hukum dan Hak Asasi Manusia Nomor 67 Tahun 2016 Tentang Pendaftaran Merek.

Dengan demikian, prinsip perlindungan hukum terhadap merek terkenal dalam konvensi internasional salah satunya Paris Convention sudah diakomodasi dengan baik maupun dengan penerapannya secara langsung oleh pemerintah Indonesia. Ini menjadi suatu point penting yang akan mempengaruhi dunia perdagangan internasional bahwa pemerintah Indonesia sudah melaksanakan dan memastikan perlindungan hukum dengan baik yang akan menguntungkan beberapa negara lain khususnya anggota Paris Convention menjadi merasa aman dan terlindungi untuk berinvestasi atau memasarkan produknya di Negara Indonesia.

\section{Kesimpulan}

Penelitian ini secara khusus membahas mengenai prinsip perlindungan hukum terhadap merek terkenal, baik menurut perundang-undangan merek di Indonesia maupun menurut Konvensi Internasional, dalam hal ini adalah Konvensi Paris. Berdasarkan penelitian yang telah dilakukan oleh penulis terkait dengan pembahasan tersebut, maka dapat disimpulkan sebagai berikut:

Merek Terkenal adalah merek yang telah diketahui oleh masyarakat umum di bidang usaha, memiliki reputasi tinggi karena diperoleh dari promosi yang gencar dan besar-besaran, investasi di beberapa negara di dunia yang dilakukan oleh pemiliknya, dan disertai bukti pendaftaran merek tersebut di beberapa Negara. Adapun secara lebih detail mengenai kriteria merek terkenal, dijelaskan dalam pasal 18 ayat (3) Peraturan Menteri Hukum dan Hak Asasi Manusia Nomor 67 Tahun 2016 Tentang Pendaftaran Merek. Adapun perlindungan hukum terhadap merek terkenal dapat disimpulkan sebagai berikut:

1. Perlindungan merek terkenal menurut Konvensi Paris

Ketentuan merek terkenal secara konkrit diatur dalam pasal 6bis Konvensi Paris, merek-merek dagang terkenal tidak dapat didaftar untuk barangbarang yang sama atau serupa oleh pihak lain selain pihak pemegang merek dagang asli. Permohonan pendaftaran tersebut harus ditolak atau dibatalkan oleh negara anggota, baik ex officio ataupun atas permohonan pemegang pendaftaran merek dagang asli. ketentuan- ketentuan yang substantif dalam Konvensi Paris dapat dibagi ke dalam 2 kategori utama, yaitu national treatment, dan hak prioritas (right of priority). Terdapat 
beberapa catatan penting mengenai isi Konvensi Paris, yaitu meliputi ketentuan tentang kriteria pendaftaran, hilangnya merek dagang karenatidak digunakan, perlindungan khusus bagi merek-merek dagang terkenal, merek dagang jasa dan merek kolektif, dan ketentuan tentang pengalihan merek (assignment). Suatu merek dapat memperoleh perlindungan hukum apabila merek tersebut telah didaftarkan, begitu juga dengan merek terkenal. Kemudian pengaturan merek terkenal menganut prinsip hak prioritas sesuai dengan Konvensi Paris. Memungkinkan pemilik merek terkenal untuk mendaftarkan mereknya dengan hak prioritas dalam satu dokumen dan satu pendaftaran yang berlaku ke semua Negara anggota.

2. Perlindungan merek terkenal menurut undang-undang merek di Indonesia Perlindungan merek terkenal di Indonesia Undang-Undang No. 20 Tahun 2016 tentang Merek dan Indikasi Geografis membagi perlindungan merek menjadi dua bentuk yaitu: Preventif (Penolakan Pendaftaran Merek dan Lisensi) serta Represif (Pembatalan Oleh Pengadilan, Sanksi Pidana dan perlindungan hukum secara Internasional terhadap merek terkenal). Penolakan terhadap pendaftaran merek yang memiliki persamaan pada pokoknya atau keseluruhan dengan merek terkenal sebagai mana dijelaskan dalam pasal 21 ayat (1) huruf b dan c Undang-Undang No. 20 Tahun 2016.

Kedua, arah perlindungan hukum merek terkenal dalam penerapan perlindungan hukum di Indonesia sebagaimana yang telah dianalisis oleh penulis telah sesuai dengan aturan hukum yang berlaku. Hal tersebut dapat dicermati berdasarkan amar putusan majelis hakim pada seluruh putusan yang telah dianalisis, adalah memenangkan merek terkenal karena terdapat itikad tidak baik dari pihak lain untuk membonceng ketenaran merek terkenal (free-riding) sehingga berdampak menyesatkan atau mengecoh masyarakat (misleading). Hal tersebut tentunya sangat merugikan eksistensi merek terkenal ditengah-tengah masyarakat. Bahwa untuk memperoleh perlindungan, merek yang sudah terdaftar harus memperpanjang mereknya sesuai dengan ketentuan perundang-undangan yang berlaku. Sebagaimana dalam Pasal 35 Undang- undang Nomor 20 Tahun 2016 Tentang Merek dan Indikasi Geografis.

\section{Bibliografi}

Admin. (2020). Penelitian Deskriptif Kualitatif.

Azed, A. B. (2006). Kompilasi Konvensi Internasional HKI yang Diratisfikasi Indonesia.. Jakarta: Prenadamedia Group Google Scholar

Djumhana, M., \& Djubaedillah, R. (2014). Hak Milik Intelektual. Bandung: T. Citra Aditya Bakti. Google Scholar

Hadi, S. M. dan L. (2003). Pembaharuan Perlindungan Hukum Merek. Jakarta: CV. 
Novindo Pustaka Mandiri. Google Scholar

Haris Munandar dan Sally Sitanggang. (2008). Mengenal Hak Kekayaan Intelektual, Hak Cipta, Paten, Merek dan Seluk-beluknya. Jakarta: Erlangga.

Hasibuan, D. E. (2003). Perlindungan merek: studi mengenai putusan pengadilan Indonesia dan Amerika Serikat. Universitas Indonesia, Fakultas Hukum, Pascasarjana. Google Scholar

Ibrahim, J. (2006). Teori dan Metodologi Penelitian Hukum Normatif. Malang: Bayumedia Publishing. Google Scholar

Isnaini, Y. (2010). Buku Pintar Haki. Bogor: Ghalia Indonesia. Google Scholar

Jened, R. (2000). Implikasi Persetujuan TRIPs Bagi Perlindungan Merek di Indonesia. Surabaya: Yuridika. Google Scholar

Kurnia, T. S., \& Darumurti, K. D. (2015). Mahkamah Konstitusi Dan Desain Hubungan Pusat-Daerah Berdasarkan Asas Negara Kesatuan. Www. Mpr. Go. Id, 117. Google Scholar

Nurul Intan Sari, S. (2015). Perlindungan Hukum Terhadap Merek Terkenal Berdasarkan Konvensi Paris Dan Perjanjian Trips Serta Penerapannya Berdasarkan Undang-Undang Nomor 15 Tahun 2001 Tentang Merek. Jurnal Yuridis, 2(2).

Purwaka, T. H. (2017). Pelindungan Merek. Jakarta: Pustaka Obor.

Purwaningsih, E. (2005). Hukum Bisnis. Bogor: Ghalia Indonesia.

Raharjo, T. (1999). Analisis Terhadap Pertimbangan Hukum Hakim dalam PutusanPutusan Perkara Merek Terkenal di Indonesia. Laporan Penelitian. Google Scholar

Saidin, O. K. (2004). Aspek hukum hak kekayaan intelektual (Intellectual property rights). Jakarta : Raja Grafindo Persada. Google Scholar

Soemitro, R. H. (1990). Metodologi penelitian hukum dan jurimetri. Jakarta: Ghalia Indonesia. Google Scholar

Sufiarina, S. (2012). Hak Prioritas Dan Hak Ekslusif Dalam Perlindungan Hki. ADIL: Jurnal Hukum, 3(2), 265-282. Google Scholar

Sutjipto, H. M. N. P., \& Purwo, N. (1984). Pengertian pokok-pokok hukum dagang Indonesia. Jakarta: Djambatan. Google Scholar

Windari, D. (2014). Pelanggaran Merek Terkenal Dan Perlindungan Hukum Bagi Pemegang Hak Dalam Perspektif Paris Convention, Trips Agreement Dan UU Merek Indonesia. Jurnal Magister Hukum Udayana (Udayana Master Law Journal), 3(3). Google Scholar 